\title{
PENINGKATAN KETERAMPILAN PROSES DAN HASIL BELAJAR IPA MENGGUNAKAN MODEL PEMBELAJARAN SAINS TEKNOLOGI MASYARAKAT (STM) PADA SISWA KELAS VI SDN 1 KALINANAS - WONOSEGORO
}

\author{
Dewi Kumala Santi \\ kumaladewi40@gmail.com \\ SDN 1 Kalinanas, Wonosegoro, Boyolali
}

\begin{abstract}
ABSTRAK
Tujuan penelitian tindakan kelas ini adalah untuk meningkatkan keterampilan proses sains (KPS), hasil belajar IPA siswa kelas VI SDN 1 Kalinanas dengan menggunakan model pembelajaran Sains Teknologi Masyarakat (STM). Jenis penelitian yang digunakan dalam penelitian ini adalah penelitian tindakan kelas, yang terdiri dari 2 siklus. Masing-masing siklus terdiri dari tahap perencanaan tindakan, pelaksanaan tindakan, observasi, dan refleksi. Intrumen pengumpulan data memakai rubrik pemilaian keterampilan proses untuk mengetahui tingkat KPS dan soal evaluasi tertulis materi perkembangbiakan tumbuhan dan hewan untuk mengetahui tingkat hasil belajar siswa. Analisis data dilakukan dengan menggunkan analisis deskriptif komparatif dimana akan diperbandingkan antara kondisi awal, pembelajaran siklus 1 dan pembelajaran siklus 2 . Hasil penelitian menunjukkan temuan-temuan bahwa model STM dapat: 1) meningkatkan KPS siswa kelas VI SDN 1 Kalinanas, Kec. Wonosegoro, Kab. Boyolali. Persentase kenaikan KPS siswa sebesar $20,96 \%$ pada pembelajaran siklus 1 dan $44,37 \%$ pada pembelajaran siklus 2. 2) Meningkatnya persentase jumlah siswa yang mencapai Kriteria Ketuntasan Minimal (KKM) pada kondisi awal adalah 31,81\% (7 siswa), 59,09\% (13 siswa) pada pembelajaran siklus 1, dan 90,90\% (20 siswa) pada pembelajaran siklus 2.

Kata kunci : keterampilan proses sains, hasil belajar, model pembelajaran sains teknologi masyarakat.

\section{PENDAHULUAN}

Lampiran Permendiknas No 22 Tahun 2006 mengemukakan tujuan mata pelajaran IPA SD/MI antara lain: 1) untuk mengembangkan rasa ingin tahu, sikap positif dan kesadaran tentang adanya hubungan saling mempengaruhi antara sains, lingkungan, teknologi dan masyarakat. 2) siswa dapat meme-

cahkan masalah yang berhubungan dengan kehidupan sehari-hari. 3) siswa mampu mendapatkan pengalaman langsung dari pembelajaran.

Namun pada kenyataannya masih jauh dari harapan. Hasil pengamatan yang dilakukan oleh peneliti dan teman sejawat di SDN 1 Kalinanas
\end{abstract}


menunjukkan bahwa guru belum menggunakan model pembelajaran yang sesuai dengan karakterisk IPA, guru masih menggunakan cara-cara tradisional yang memfokuskan pada pemberian informasi dan pengetahuan kepada siswa dalam mentransfer pengetahuan sebanyak mungkin.

Kondisi tersebut berdampak pada KPS dan hasil belajar IPA siswa. Pada pembelajaran materi perkembangbiakan tumbuhan dan hewan hanya ada 5 siswa $(22,72 \%)$ menunjukkan KPS siswa berada pada kategori tinggi, 4 siswa $(18,18 \%)$ berada pada kategori sedang, dan 13 siswa $(59,09 \%)$ berada pada kategori rendah.

Rendahnya KPS ini berdampak pada hasil belajar siswa. Data awal tingkat kompetensi hasil belajar siswa dengan KKM 70 ternyata hanya ada 7 siswa $(31,81 \%)$ yang telah mencapai KKM dan rerata skornya berada pada kategori tinggi, sedangkan 5 siswa $(22,72 \%)$ belum mencapai KKM dan rerata skornya berada pada kategori sedang, dan 10 siswa $(45,45 \%)$ masih jauh di bawah KKM yang rerata skornya berada pada kategori rendah.

Melihat kondisi seperti itu peneliti berupaya melakukan perbaikan pembelajaran dalam rangka meningkatkan KPS dan hasil belajar IPA. Kajian pustaka yang dilakukan peneliti menemukan informasi berbagai model pembelajaran yang sesuai untuk meningkatkan KPS dan hasil belajar IPA.
Salah satu jenis model pembelajaran yang tepat untuk pembelajaran IPA SD adalah model pembelajaran STM karena siswa dapat belajar melalui pengalaman langsung, dan menggunakan alat-alat dan media belajar yang ada di lingkungan anak sendiri.

Berdasarkan latar belakang di atas, permasalahan penelitian yang akan dipecahkan dalam Penelitian Tindakan Kelas ini adalah seberapa tinggi peningkatan KPS dan hasil belajar siswa menggunakan model STM.

\section{KAJIAN PUSTAKA}

\section{Hakikat IPA}

IPA merupakan salah satu ilmu yang mempelajari tentang gejala-gejala yang terjadi di alam yang didasarkan pada hasil pengamatan dan percobaan yang dilakukan oleh manusia (Sawatomo, 2009:3). Menurut Triyanto (2010:36) IPA merupakan kumpulan teori yang penerapannya terbatas pada gejala-gejala alam, hingga akhirnya berkembang melalui metode ilmiah.

Dari pendapat-pendapat di atas dapat IPA didefinisikan sebagai kumpulan pengetahuan tentang gejala-gejala alam yang diperoleh dari hasil pemikiran dan penyelidikan yang dilakukan melalui eksperimen dengan menggunakan metode ilmiah. IPA merupakan ilmu pengetahuan tentang gejala alam yang dituangkan berupa fakta yang teruji kebenarannya ,dengan mempelajarinya diharapkan dapat menambah pengetahuan tentang alam 
sekitar serta manfaatnya untuk kehidupan sehari-hari.

"Sains" sering diartikan dengan Ilmu Pengetahuan Alam. Secara umum sains mempunyai arti 1) kegiatan mengumpulkan informasi secara sistematik tentang alam sekitar, 2) pengetahuan yang didapat melalui suatu proses kegiatan, 3) nilai-nilai dan sikap ilmuwan menggunakan proses ilmiah dalam memperoleh pengetahuan. Sains merupakan suatu proses kegiatan yang dilakukan para ilmuwan sains dalam memperoleh pengetahuan dan sikap terhadap proses kegiatan tersebut. (Patta Bundu, 2006:10). Dari pengertian-pengertian di atas, sains mempunyai 3 komponen, yaitu 1) proses ilmiah, misalnya mengamati, mengklasifikasi, memprediksi, merancang, dan melakukan eksperimen, 2) produk ilmiah, misalnya prinsip, konsep, hukum, dan teori, dan 3) sikap ilmiah, misalnya rasa ingin tahu, obyektif, dan jujur.

Melihat hakikat pembelajaran IPA seperti yang telah diuraikan di atas maka guru perlu mempertimbangkan rancangan tentang KPS, menggunakan model pembelajaran yang dapat meningkatkan KPS yaitu STM. Uraian tentang KPS, dan STM akan di bahas pada bagian tersendiri.

\section{Keterampilan Proses Sains (KPS)}

Untuk mengembangkan ilmu dan pengetahuan tentang alam, seseorang perlu menguasai beberapa keterampilan dasar yang biasa disebut dengan keterampilan proses. Saat siswa sedang melakukan keterampilan proses, misal mengamati, siswa sebenarnya tidak hanya memperhatikan suatu objek, tetapi juga menghubungkan apa yang sedang dia amati dengan apa yang telah dia diketahui. Oleh sebab itu keterampilan proses sesungguhnya bukanlah sekedar keterampilan motorik tetapi juga melibatkan keterampilan berpikir.

Pendekatan keterampilan proses pada hakikatnya merupakan suatu pengelolaan kegiatan belajar mengajar yang menitik beratkan pada siswa agar siswa menjadi aktif dan kreatif dalam proses perolehan hasil belajar. Seiring dengan perkembangan IPTEK, pendekatan keterampilan proses ini dianggap sebagai pendekatan yang paling sesuai dengan proses pembelajaran di SD.

Prinsip-prinsip tentang pendekatan ini menjadi hal yang mutlak harus dipahami. Prinsip-prinsip tersebut antara lain: 1) kemampuan mengamati merupakan keterampilan yang sangat penting utnuk mendapatkan pengetahuan, pengamatan dilakukan dengan memanfaatkan semua panca indera yang biasa digunakan untuk memperhatikan hal yang diamati, kemudian mencatat apa yang diamati, memilah-milah bagiannya berdasarkan kriteria tertentu, juga berdasarkan tujuan pengamatan, serta mengolah hasil pengamatan dan menuliskan hasilnya. 2) kemampuan mengklasifikasi merupakan kemampuan menge- 
lompokkan sesuatu yang berupa benda, fakta, informasi, dan gagasan. 3) kemampuan menemukan hubungan yang termasuk dalam kemampuan ini adalah: fakta, informasi, gagasan, pendapat, ruang, dan waktu. 4) kemampuan membuat prediksi, kemampuan ini disebut juga kemampuan menyusun hipotesis yaitu suatu perkiraan untuk menentukan suatu kejadian atau pengamatan tertentu. 5) kemampuan melaksanakan penelitian yaitu kegiatan menguji gagasan melalui kegiatan eksperimen. 6) kemampuan mengumpulkan dan menganalisis data, dalam kemampuan ini siswa perlu menguasai cara-cara mengumpulkan data. 7) kemampuan mengkomunikasikan data, dalam hal ini siswa perlu dilatih untuk mengkomunikasikan hasil penemuannya kepada orang lain dalam bentuk laporan penelitian.

Keunggulan pendekatan keterampilan proses ini antara lain : 1) Siswa terlibat langsung dengan obyek yang sedang dipelajari, sehingga mempermudah siswa dalam memahami pelajaran. 2) Siswa dapat menemukan sendiri konsep-konsep yang dia pelajari. 3) Melatih siswa untuk berpikir kritis. 4) Melatih siswa untuk bertanya dan ikut aktif dalam proses pembelajaran. 5) Mendorong siswa untuk menemukan konsep-konsep baru. 6)
Member kesempatan siswa untuk belajar menggunakan metode-metode ilmiah.

\section{Model Pembelajaran Sains Teknologi Masyarakat}

Sains Teknologi Masyarakat (STM) merupakan terjemahan dari bahasa Inggris science technology society (STS), yaitu, suatu usaha untuk menyajikan IPA dengan mempergunakan masalah-masalah dari dunia nyata. pembelajaran dengan pendekatan STM haruslah diselenggarakan dengan cara mengintegrasikan berbagai disiplin (ilmu) dalam rangka memahami berbagai hubungan yang terjadi di antara sains, teknologi dan masyarakat. Pendidikan sains dengan menggunakan pendekatan STM adalah suatu bentuk pengajaran yang tidak hanya menekankan pada penguasaan konsep-konsep sains saja tetapi juga menekankan pada peran sains dan teknologi di dalam berbagai kehidupan masyarakat dan menumbuhkan rasa tanggung jawab sosial terhadap dampak sains dan teknologi yang terjadi di masyarakat (Prayekti, 2002: 777). Pembelajaran dengan pendekatan STM mengembangkan materi dalam lingkup yang dapat digambarkan sebagai berikut : 


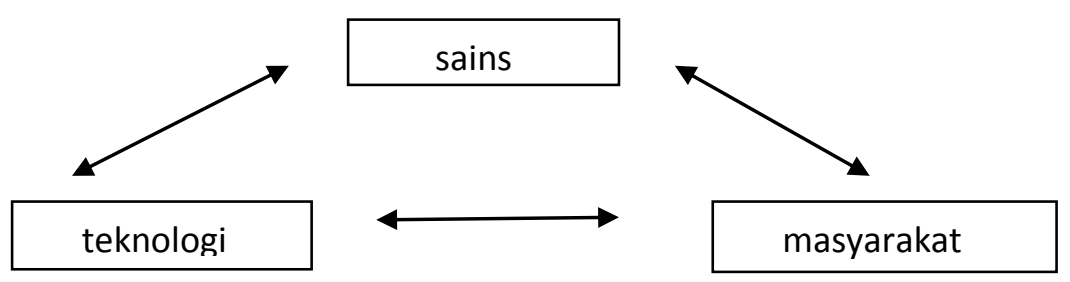

Gambar 1. Hubungan antara sains, teknologi, dan masyarakat

Gambar 1 menunjukkan bahwa sains, teknologi, dan masyarakat sangat erat hubungannya. Siswa berinteraksi dengan lingkungan sosial (masyarakat), lingkungan alam, dan lingkungan buatan (teknologi). Teknologi ini diciptakan oleh manusia untuk memenuhi kebutuhan hidupnya. Teknologi dan sains saling melengkapi sebab sains merupakan pengetahuan yang sistematis tentang alam sedangkan teknologi merupakan metode sistematis yang dilakukan manusia untuk memenuhi kebutuhan hidupnya. Tsujuan pendekatan STM secara umum antara lain adalah: 1) Peserta didik mampu menghubungkan realitas sosial dengan topic pembelajaran di dalam kelas. 2) Peserta didik mampu menggunakan berbagai jalan/ perspektif untuk mensikapi berbagai isu/ situasi yang berkembang di masyarakat berdasarkan pandangan ilmiah. 3) Peserta didik mampu menjadikan dirinya sebagai warga masyarakat yang memiliki tanggung jawab sosial.

Tahapan-tahapan model pembelajaran Sains Teknologi Masyarakat (STM) menurut Asyari (2006) antara lain: 1) Tahap invitasi, Pada tahap ini guru merangsang peserta didik mengingat atau menampilkan kejadiankejadian yang ditemui di masyarakat baik melalui media cetak maupun media elektronik yang dapat merangsang siswa untuk bisa ikut mengatasinya. 2) Tahap eksplorasi. Pada tahap ini siswa melalui aksi dan reaksinya sendiri berusaha untuk mencari jawaban sementara yang telah dibuat dengan mencari data dari berbagai sumber informasi (buku, koran, majalah, lingkungan, nara sumber, instansi terkait, atau melakukan percobaan) hasil yang diperoleh peserta didik hendaknya berupa hasil analisis dari data yang diperoleh. 3) Tahap penjelasan dan solusi. Pada tahap ini peserta didik diajak untuk mengkomunikasikan gagasan yang diperoleh dari analisis informasi yang didapat, menyusun suatu konsep baru, meninjau dan mendiskusikan solusi yang diperoleh. Sehingga untuk memantapkan konsep yang diperoleh siswa tersebut guru perlu memberikan umpan balik/peneguhan. 4) Tahap penentuan tindakan. Pada tahap ini siswa diajak untuk membuat suatu keputusan 
dengan mempertimbangkan penguasaan konsep sains dan keterampilan yang dimiliki untuk berbagai gagasan dengan lingkungan, atau dalam kedudukan peserta didik sebagai pribadi atau sebagai masyarakat. Pengambilan tindakan ini diantaranya dapat berupa kegiatan pengambilan keputusan, penerapan pengetahuan, membagi informasi, dan gagasan.

Berdasarkan hakikat IPA, karakteristik pembelajaran IPA seperti telah diuraikan di atas, maka model STM dapat dijadikan salah satu alternative model pembelajaran IPA di SD. Implementasi Model STM, secara teoretik dapat meningkatkan kompetensi keterampilan proses sains siswa yang nantinya akan berdampak pada penguasaan konsep-konsep sains.

\section{METODE PENELITIAN}

Penelitian Tindakan Kelas ini dilakukan di SDN 1 Kalinanas, Kec. Wonosegoro, Kab. Boyolali pada mata pelajaran IPA kelas VI semester 1 tahun pelajaran 2014/2015. Pelaksanaan penelitian tindakan kelas ini dilakukan melalui tahapan penyusunan proposal penelitian, penyusunan instrument, pelaksanaan tindakan dalam rangka pengumpulan data, analisi data, dan pembahasan hasil penelitian serta penyusunan laporan PTK. Waktu pelaksanaan setiap tahap-tahap PTK tersebut adalah: 1) penyusunan proposal penelitian dilakukan pada bulan Juli 2014 , 2) penyusunan instrument dilakukan minggu ke-3 bulan Agustus, 3) pelaksanaan pembelajaran siklus 1 dilakukan pada minggu ke-2 bulan September, 4) pembelajarn siklus 2 dilaksanakan minggu ke-3 bulan September tahun 2014. Penentuan jadwal ini disesuaikan dengan uturan kompetensi dasar pada silabus dan kalender pendidikan.

Subyek dalam penelitian ini adalah siswa kelas VI yang berjumlah 22 siswa yang terdiri dari 14 siswa lakilaki dan 8 siswa perempuan. Sumber data primer di dapat dari hasil pengukuran variable penelitian yaitu : 1) skor tingkat keterampilan proses sains siswa dan, 2) hasil belajar siswa. Sumber data sekunder didapat dari : 1) tingkat aktifitas siswa saat proses pembelajarann dan, 2) tingkat aktivitas guru saat menyampaikan materi pembelajaran.

Teknik pengumpulan data dalam penelitian ini menggunakan teknik tes dan non tes. Instrument non tes berupa instrument pengumpulan data tentang keterampilan proses sains siswa dengan menggunakan rubrik keterampilan proses sains, dan instrument pengumpulan data hasil belajar IPA menggunakan tes tertulis. Kisi-kisi instrument keterampilan proses sains mencakup 7 item dari 7 komponen, yaitu komponen keterampilan mengamati (item no 1), mengklasifikasi (item no 2), menemukan hubungan (item no 4), memprediksi (item no 3), melakukan kegiatan penelitian (item no 6), 
mengumpulkan data (item no 5), dan mengkomunikasikan (item no 7). Kisikisi instrument penilaian hasil belajar IPA mencakup 20 item soal, terdiri dari : penggolongan perkembangbiakan vegetatif (item no 1,2,3), bahan-bahan yang digunakan untuk mencangkok (item no 4), langkah-langkah mencangkok (item no 5,6,7,8,9,10), tumbuhan yang dapat dicangkok (item no 11, 12), kelebihan mencangkok (item no 13), kekurangan mencangkok (item no 14), pengertian cangkok (item no 15).

Analisis data yang digunakan adalah teknik analisis deskriptif komparatif. Data kuantitatif yang diperoleh kemudian dideskripsikan dalam bentuk kalimat penjelasan, begitu juga dengan data hasil evaluasi siswa. Data-data yang diperoleh dari tiap-tiap siklus kemudian dikomparasikan untuk memastikan ada tidaknya peningkatan hasil belajar dan peningkatan keterampilan proses sains siswa. Tolok ukur keberhasilan pelaksanaan penelitian tindakan kelas ini ditetapkan lewat indikator kinerja sebagai berikut : 1) pada siklus 1 persentase jumlah siswa yang mencapai KKM sebesar 59,09\%, sedangkan pada siklus 2 mencapai $90,9 \%, 2)$ meningkatnya keterampilan proses sains siswa rata-rata $33 \%$ pada tiap-tiap siklusnya.

Prosedur PTK ini terdiri dari empat tahapan yang saling terkait dan berkesinambungan, yaitu perencanaan (planning), tindakan (action), observasi (observe), refleksi (reflect) (Ditjen Dikti, 1999:25)

\section{HASIL DAN PEMBAHASAN \\ Deskripsi hasil Tiap Siklus dan Antar Siklus}

Setelah melakukan analisa terhadap data yang diperoleh dari 2 siklus yang dilaksanakan, maka dapat disimpulkan bahwa model pembelajaran Sains teknologi masyarakat materi perkembangbiakan tumbuhan dan hewan menunjukkan peningkatan keterampilan proses sains dan ketuntasan hasil belajar siswa. Tabel 1 merangkum komparasi tingkat keterampilan proses sains dari kondisi awal, pemebelajarn siklus 1 , dan pemebelajaran siklus 2 .

Tabel 1 Komparasi Keterampilan Proses Sains

\begin{tabular}{|c|c|c|}
\hline \multirow{2}{*}{ pembelajaran } & \multicolumn{2}{|c|}{ Tingkat Keterampilan Proses Sains } \\
& Mean & \% kenaikan \\
\cline { 2 - 3 } & 12,50 & - \\
\hline Kondisi Awal & 15,12 & 20,96 \\
\hline Siklus 1 & 21,83 & 44,38 \\
\hline Siklus 2 &
\end{tabular}


Dari tabel 1 di atas diperoleh temuan : a) pada kondisi awal rata-rata tingkat keterampilan proses sains siswa hanya mencapai 12,50 (skor maksimal 28), b) pada pemebelajaran siklus 1 rata-rata tingkat keterampilan proses mencapai 15,12. Capaian ini menunjukkan mulai adanya pening- katan keterampilan sebesar 20,96\%, c) pada pembelajaran siklus 2 , reratarata keterampilan proses sains mencapai 21,83, data ini menunjukkan adanya peningkatan drastis keterampilan proses sains siswa sebesar $44,38 \%$.

\section{Grafik 1}

Komparasi Mean dan Ketuntasan Hasil Belajar Siswa

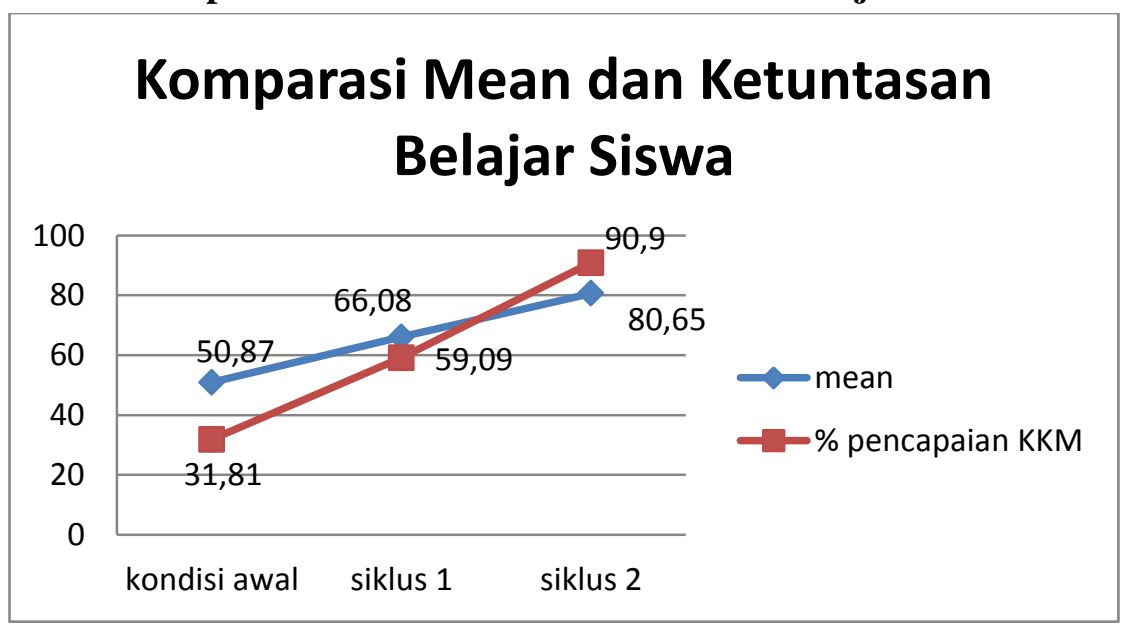

Kenaikan mean hasil belajar siswa dan persentase jumlah ketuntasan belajar siswa dirangkum dalam grafik 1. Dari grafik 1 di atas diperoleh data yaitu : a) pada kondisi awal mean hasil belajar hanya mencapai 50,87 sedangkan persentase jumlah siswa yang mencapai KKM hanya 31,81\% (7 siswa). b) pada pembelajaran siklus 1 mean hasil belajar siswa menjadi 66,08 dengan persentase jumlah siswa yang mencapai KKM sebesar 59,09\% (13 siswa). c) pada pembelajaran siklus 2 , mean hasil belajar siswa mengalami peningkatan menjadi 80,65 dengan

persentase jumlah siswa yang mencapai KKM sebesar 90,90\% (20 siswa).

Temuan Penelitian dan Pembahasan

1. Keberhasilan model saians teknologi masyarakat (STM) dalam meningkatkan keterampilan proses sains siswa. Data pada tabel keterampilan proses sains siswa pada kondisi awal, pembelajaran siklus 1 dan siklus 2 menunjukkan temuan rerata keterampilan proses sains pada kondisi awal 12,5, pada siklus 1 15,12, dan pada siklus 2 21,83. 
Temuan ini memperlihatkan adanya peningkatan tingkat keterampilan proses sains siswa. Persentase peningkatan ini adalah $20,96 \%$ pada pembelajaran siklus 1 , dan $44,37 \%$ pada pembelajaran siklus 2 . Temuan pada siklus 1 dan siklus 2 ini telah mencapai keberhasilan. Keberhasilan dari penelitian ini bermakna bahwa siswa mampu mengamati, mengkalsifikasi, menemukan hubungan, memprediksi, melakukan penelitian, mengumpulkan data, dan mengkomunikasikan. Hasil temuan ini sejalan dengan penelitian Siswantara, manuaba \& Meter (2013), Catur Putra Indra Septiawan (2010).

\section{Keberhasilan model Sains} Teknologi Masyarakat (STM) dalam meningkatkan hasil belajar siswa.

Data pada grafik 1 hasil belajar siswa pada kondisi awal, pembelajaran siklus 1 dan siklus 2 menunjukkan temuan pada kondisi awal mean hanya 50,87, pada pembelajaran siklus 1 mean meningkat menjadi 66,08, dan mean pada siklus 2 meningkat kembali menjadi 80,65 . Temuan ini mengindikasikan adanya peningkatan hasil belajar IPA siswa. besaran peningkatan pada siklus 1 adalah $59,09 \%$ dan pada siklus 2 menjadi 90,9\%, ternyata temuan ini telah mencapai keberhasilan.

Temuan ini sejalan dengan penelitian Siwantara, Manuaba \& Meter (2013), Apriyana E (2002), Arifin M.H (2003).

\section{SIMPULAN DAN SARAN}

\section{A. Simpulan}

Berdasarkan hasil penelitian dan pembahasan, dapat disimpulkan bahwa Model Pembelajaran sains Teknologi Masyarakat dapat :

1. Meningkatkan keterampilan proses sains siswa kelas VI SDN 1 Kalinanas, Kec. Wonosegoro, Kab. Boyolali sebesar 20,96\% pada pembelajaran siklus 1 dan $44,37 \%$ pada pembelajaran siklus 2.

2. Meningkatnya hasil belajar siswa kelas VI SDN 1 Kalinanas Kec. Wonosegoro, Kab. Boyolali sebesar 59,09\% pada pembelajaran siklus 1 dan 90,9\% pada pembelajaran siklus 2 .

\section{B. Saran}

Saran yang dapat diberikan dalam penelitian ini adalah :

1. Guru hendaknya menggunakan model pembelajaran sains teknologi masyarakat pada pembelajaran IPA.

2. Guru hendaknya membangun partisipasi aktif siswa dalam proses kegiatan belajar mengajar. 


\section{DAFTAR PUSTAKA}

Apriyana, E. (2002) Penerapan Model Pendekatan Sains Teknologi Masyarakat dengan Pendekatan Bermain Peran untuk meningkatkan Pemahaman Konsep, Sikap, dan Keterampilan Siswa SMU menerapkan Konsep Pelestarian Sumber Daya Alam Hayati. Tesis SPs UPI Bandung: Tidak Diterbitkan.

Arifin, M.H. (2003) Pengaruh Penggunaan Pendekatan Sains Teknologi Masyarakat Terhadap Prestasi Belajar Fisika. Skripsi FPMIPA UPI Bandung: Tidak diterbitkan.

Bundu, Patta, (2006). Penilaian Keterampilan Proses dan SIkap Ilmiah Dalam Pembelajaran Sains. Jakarta: Depdiknas

Depdiknas, (2006). Lampiran Permendiknas No. 22 Tahun 2006 tentang Standar Isi Kurikulum SD/MI tahun 2006. Jakarta: Depdiknas.

Kemendikbud, (2014). Materi Pelatihan Implemetsi Kurikulum 2013. Jakarta: badan Pengembangan Sumber daya Manusia Pendidikan dan kebudayaan dan Penjaminan Mutu pendidikan Kementerian Pendidikan dan Kebudayaan.

Prayekti. (2002). Pembelajaran Kooperatif Tipe Student Team Achievement Division di Sekolah Dasar, Jurnal Pendidikan (4) 2

Samatowa, Usman, (2009). Pembelajaran Ipa di Sekolah Dasar. Jakarta. PT Indeks Jakarta barat

Siswantara, Manuaba \& Meter (2013. Penerapan Model Problem Based Learning (PBL) Untuk Meningkatkan Aktivitas dan hasil Belajar IPA Siswa Kelas IV SD Negeri 8 Kesiman. Jurnal Garuda Portal, (1):1-10.

Trianto. 2010. Mengembangkan Model Pembelajaran Tematik. Jakarta : Prestasi Pustaka 